\title{
The Influence of Non-selective Oxidation on Differently Pre-treated Cotton Yarns Properties
}

\author{
Emilija TOSHIKJ, Igor JORDANOV*, Vesna DIMOVA, Biljana MANGOVSKA
}

University Ss. Cyril and Methodius, Faculty of Technology and Metallurgy, Department of Textiles, Skopje, Macedonia

cross $^{\text {ref }}$ http://dx.doi.org/10.5755/j01.ms.22.3.12110

Received 24 April 2015; accepted 21 October 2015

\begin{abstract}
Differently pre-treated cotton yarns were subjected to non-selective oxidation with perchloric acid and the effects of pretreatment processes on oxidation were studied through functional groups quantity, and degradation through mechanical properties and degree of polymerization. Different pre-treatments include, different scouring (with alkali, alkaline and acid pectinase), mercerization-different scouring as well as different scouring-mercerization. The quantity of functional groups was studied by measuring carboxyl groups with methylene blue and calcium-acetate methods and aldehyde groups with iodine and tetrazolium (TTC) methods. Pre-treatment processes affect the degree of elimination of non-cellulosic components of cotton and have strong influence on oxidation process. The non-selective oxidation of enzymatic scoured cotton with perchloric acid has introduced carboxyl and aldehyde groups without serious degradation of cotton yarns, confirmed by only $15 \%$ decreasing of tensile strength and $8 \%$ decreasing of degree of polymerization.

Keywords: oxidation, cotton, degradation, carboxyl groups, functionalization.
\end{abstract}

\section{INTRODUCTION}

Cellulose is the largest and most widely used polysaccharide with ability to absorb moisture, with high thermal stability, good biocompatibility, relatively low cost and good mechanical properties. Modification of cellulose is an interesting route for preparing new polymers with specific properties. It may be obtained either by physical methods or chemical means. Physical methods are mechanical, thermal, plasma, laser, corona etc. The chemical methods are divided on chemical modification of polymers and application of chemicals (biopolymers). Chemical modifications are oxidation, treatments with enzymes, graft copolymerization, mercerization, esterification etc. [1]. The oxidation of cellulose is a typical method for modification under mild aqueous condition where introduction of aldehyde or carboxylic groups can be easily done by different chemicals, controlling $\mathrm{pH}$, temperature, treatment time as well as state of the starting cellulose. Oxidation can be done on primary (at C-6) or secondary hydroxyl groups (at C-2 and C-3) and can be selective or non-selective. Selective oxidation is achieved with $\mathrm{K}$ - or Na-periodate, TEMPO or PINO [2-4], while non-selective with $\mathrm{HClO}_{4}$, permanganate, hypochlorites and hydrogen peroxide [5].

Hydrogen peroxide, sodium hypochlorite and sodium periodate have been studied for different kind of textile materials like cotton gauze compresses, cotton knitted bandage and unwoven textile of viscose/PES which were preliminary alkaline scoured by $14 \% \mathrm{NaOH}$ [5]. Higher aldehyde groups were accounted for cotton gauze, followed by knitted bandages and unwoven textile independent of used oxidizing agent, providing that the structure of the cotton textile material is very important. The highest quantity of aldehyde groups was found on

\footnotetext{
* Corresponding author. Tel.: +389-2-3088255; fax: +389-2-3065389.

E-mail address: jordanov@tmf.ukim.edu.mk (I. Jordanov)
}

oxidized cellulose by sodium periodate, followed by hypochlorite and peroxide. Periodate oxidation leads to the highest depolymerization and cause significant degradation [6]. Oxidized native cotton fibres with TEMPO showed a minimum increase of fineness, substantial decrease of tensile strength and a higher amount of carboxyl groups [7] with substantial decrease in DP [8].

Oxicellulose serve as useful intermediates for cellulose based materials that can adsorb some chemicals such as metals, proteins, polymers and dyes and are widely used in pharmaceutics, drug and gene delivery, food industry, cosmetic products, polymer composites and metal absorbent [9]. Obtained dialdehyde celluloses can be used to immobilize proteins, drugs or hormones [10] or amino polysaccharides by reaction with their amino functional groups.

Oxidation of cotton, commonly is applied after conventional pre-treated processes such as scouring, bleaching or mercerization [5,6]. In traditional alkaline scouring cuticle is completely removed and cotton can be degraded through oxicellulose formation. Enzymatic scouring with pectinase, through its selective action, breaks down the pectin in the cuticle and thereby assists the removal of waxes, proteins and other non-cellulose components. Mild working conditions and selective action avoid degradation of cotton [11].

Previous worldwide researches were mainly focused on analysis of charge on oxidized cotton prepared under more aggressive conditions, so, less attention has been given to oxidation of cotton pre-treated under mild conditions named as a ,green" treatment which protects the fiber structure as well as environment.

Our previous research works, were mainly focused on evaluating the changes on cotton surface and non-cellulosic components after different, green” pre-treatments [12, 13]. Different pre-treatment conditions have strongly influenced the surface charge on cotton fiber, reduced the non- 
cellulosic components, but they were still detected at the fiber surface $[12,13]$.

The goal of this paper is to investigate the influence of different pre-treatment processes on the non-selective oxidation of cotton with perchloric acid including different scouring (with alkali, alkaline and acid pectinase), mercerization and different scouring as well as different scouring and mercerization. Quantity of carboxyl and aldehyde group as well as the degradation were studied on oxidized cotton yarns and compared to un-oxidized.

\section{EXPERIMENTAL DETAILS}

\subsection{Materials}

Piled, ring-worsted cotton yarn with linear density of $30 \times 2$ tex spun with 330 twists/m was supplied by VETEX AD Veles, Macedonia.

\subsection{Treatment methods}

Raw and mercerized cotton yarns (as hanks) were scoured by alkaline, alkaline pectinase and acid pectinase scouring.

Mercerization was done on Jäegli hank mercerization equipment by rolling the hanks in $23.5 \% \mathrm{NaOH}$ solution and $1 \mathrm{~g} / \mathrm{dm}^{3}$ Subitol MEZ-N (CHT-Germany), wetting agent at $18{ }^{\circ} \mathrm{C}$. Next, the hanks were extended by application of tension to the original length, rinsed with hot $\left(80{ }^{\circ} \mathrm{C}\right)$ and cold $\left(20^{\circ} \mathrm{C}\right)$ water for 1 min under tension, neutralized and rinsed, and dried at $20^{\circ} \mathrm{C}$.

Alkaline scouring was done using $3.2 \mathrm{~g} / \mathrm{L} \mathrm{NaOH}$ in presence of $2 \mathrm{ml} / \mathrm{L}$ Cotoblanc HTD-N anionic surfactant (CHT) and $1 \mathrm{ml} / \mathrm{l}$ Kemonecer NI nonionic surfactant (Kemo-Croatia), 16.6 : $1 \mathrm{LR}$, at $100{ }^{\circ} \mathrm{C}$ for $60 \mathrm{~min}$.

Alkaline pectinase scouring was done using $0.666 \mathrm{~g}$ BioPrep 3000L per $\mathrm{kg}$ material, 16.6:1 LR, containing $0.15 \mathrm{~g} / \mathrm{L} \quad \mathrm{Na}_{3} \mathrm{PO}_{4}(\mathrm{pH}$ 9) in the presence of $1 \mathrm{ml} / \mathrm{L}$ Kemonecer NI at $55^{\circ} \mathrm{C}$ for $30 \mathrm{~min}$. Then, $0.4 \mathrm{~g} / \mathrm{L}$ EDTA was added to the scouring bath and the temperature raise to $90{ }^{\circ} \mathrm{C}$ for 15 min to stop enzymatic activity.

Acid pectinase scouring was done with $0.625 \mathrm{~g} \mathrm{NS}$ 29048 per kg material, 16.6 : $1 \mathrm{LR}$, in acetic buffer ( $\mathrm{pH} 4)$, in the presence of $1 \mathrm{ml} / \mathrm{L}$ Kemonecer NI, at $45^{\circ} \mathrm{C}$ for $30 \mathrm{~min}$. After that, $0.8 \mathrm{~g} / \mathrm{L}$ EDTA was added and the temperature was raised to $90{ }^{\circ} \mathrm{C}$ for $15 \mathrm{~min}$ to stop enzymatic activity. After all used types of scouring yarns were rinsed at $90{ }^{\circ} \mathrm{C}$ for $10 \mathrm{~min}$ at $70{ }^{\circ} \mathrm{C}$ for $10 \mathrm{~min}$, and once with cold water to full neutralization.

Demineralization was done with $0.01 \mathrm{M} \mathrm{HCl}$, $35: 1 \mathrm{LR}$, at $20^{\circ} \mathrm{C}$ for $120 \mathrm{~min}$. Yarns were rinsed five times with cold water for $15 \mathrm{~min}$. After demineralization yarns were oxidized without drying. Oxidation was done with $1 \mathrm{M} \mathrm{HClO}_{4}, 35: 1 \mathrm{LR}$, at $20^{\circ} \mathrm{C}$ for $12 \mathrm{~h}$. Yarns were rinsed five times with cold water for $15 \mathrm{~min}$ and dried at room temperature.

Sample codes and linear densities of the used yarns are given in Table 1.

\subsection{Testing methods}

Determination of carboxyl groups by Methylene blue adsorption (MB) was carried out according to Fras L. et al. [6].
Determination of carboxyl groups by Ca-acetate method [14]. A $1 \mathrm{~g}$ sample was added in $100 \mathrm{ml}$ distilled water and $60 \mathrm{ml} 0.25 \mathrm{M} \mathrm{Ca-acetate}$ solution, and $12 \mathrm{~h}$ treatment at room temperature with frequent shaking were done facilitated completion of the interchange: complexometric titration method (EDTA). $25 \mathrm{ml}$ of the calcium-acetate solution were titrated with $0.1 \mathrm{M}$ EDTA, using eriochrom black $\mathrm{T}$ at $\mathrm{pH} 10$ by the addition of $5 \mathrm{ml}$ $\left(\mathrm{NH}_{4} \mathrm{Cl}+\mathrm{NH}_{4} \mathrm{OH}\right)$ buffer. The quantity of carboxyl groups is calculated using equation:

$$
\operatorname{COOH}(\mathrm{mmol} / \mathrm{g})=\frac{\left(V_{a}-V_{b}\right) \cdot C}{m},
$$

where $V_{b}$ is the consumption of titrating reagent (EDTA) for the sample $(\mathrm{ml}) ; V_{a}$ is the consumption of titrating reagent (EDTA) for the blank sample $(\mathrm{ml}) ; C$ is the concentration of the titrating reagent $(\mathrm{mol} / \mathrm{l}) ; m$ the weight of sample $(\mathrm{g})$.

Neuralization titration method $(\mathrm{NaOH}) .25 \mathrm{ml}$ of the calcium-acetate solution were titrated with $0.01 \mathrm{M} \mathrm{NaOH}$, using thymol blue indicator. The quantity of carboxyl groups is calculated using equation:

$\mathrm{COOH}(\mathrm{mmol} / \mathrm{g})=\frac{\frac{160}{25} \cdot 0.01 \mathrm{M} \cdot \mathrm{V}(\mathrm{NaOH})}{m}$,

where $0.01 \mathrm{M}$ is the concentration of $\mathrm{NaOH} ; V$ is the volume $(\mathrm{ml})$ of $\mathrm{NaOH}$ solution used for titration; $m$ is the weight of oxidized or un-oxidized cotton yarns $(\mathrm{g})$.

Table 1. Codes and linear densities of the differently pre-treated cotton yarns

\begin{tabular}{|l|l|c|}
\hline Codes & \multicolumn{1}{|c|}{ Differently pre-treated cotton yarns } & $\begin{array}{c}\text { Linear } \\
\text { density } \\
\text { (tex) }\end{array}$ \\
\hline R & Raw & 58.36 \\
\hline SA & Scoured with NaOH & 58.10 \\
\hline SB & Scoured with BioPrep 3000 L & 59.39 \\
\hline SN & Scoured with NS 29048 & 57.37 \\
\hline MSA & Mercerized, scoured with NaOH & 58.35 \\
\hline MSB & Mercerized, scoured with BioPrep 3000 L & 57.46 \\
\hline MSN & Mercerized, scoured with NS29048 & 58.52 \\
\hline SAM & Scoured with NaOH and mercerized & 58.75 \\
\hline SBM & Scoured with BioPrep 3000 L and mercerized & 59.71 \\
\hline SNM & Scoured with NS 20948 and mercerized & 57.80 \\
\hline
\end{tabular}

Determining the aldehyde groups by modified iodine method (I). $0.08 \mathrm{~g}$ sample was suspended in a solution of $30 \mathrm{~cm}^{3} 0.008 \mathrm{M} \mathrm{NaOH}$ and $10 \mathrm{~cm}^{3} 0.001 \mathrm{M} \mathrm{J}_{2}$ solution. After standing $3 \mathrm{~h}$ at room temperature with frequent shaking, $25 \mathrm{~cm}^{3}$ portion of the solution, $15 \mathrm{~cm}^{3} 0.3 \mathrm{M} \mathrm{HCl}$ were titrated with $0.0075 \mathrm{M} \mathrm{Na}_{2} \mathrm{~S}_{2} \mathrm{O}_{3} \cdot 5 \mathrm{H}_{2} \mathrm{O}$, using starch as indicator.

Aldehyde groups by tetrazolium method (TTC) were measured according to Strlic and Pihlar [15]. Presented results for carboxyl and aldehyde groups are mean values of 3 measurements at confidence level of $95 \%$.

Tensile strength $(\mathrm{F})$, elongation $(\varepsilon)$ and work of rupture (A) were carried out according to EN ISO 2062 1995 (2009) on Tinus Olsen (SDL ATLAS) using test speed of $100 \mathrm{~mm} / \mathrm{min}$ and gauge length of $300 \mathrm{~mm}$. Presented results are the mean values of 20 measurements at confidence level of $95 \%$. 
Degree of polymerization (DP) was determined viscosimetrically after dissolving the sample in EWNN (sodium salt of ferric tartaric acid) [6].

All investigated parameters were analyzed by main effects analysis of variance (ANOVA), considering the oxidation (variable A), course of pre-treatment (variable B) and type of scouring (variable $\mathrm{C}$ ) using STATISTICA 6 program.

\section{RESULTS AND DISCUSSION}

\subsection{Analysis of functional groups on un-oxidized differently pre-treated cotton yarns}

Oxidation is performed to produce cellulose derivate for specific applications. Pre-treatment processes of cotton are very important and may be crucial regarding its further oxidation. The results of analyzed surface residues through dyeing with different dyes published in our previous publications $[12,13]$ are given in Table 2 , and the quantity of aldehyde and carboxyl groups before oxidation, obtained by method used in this work, is given in Table 3 . Cotton yarns were dyed with direct and reactive dyes for determination of cellulosic purity and oil red, methylene blue (basic dye) and bemacide blue (acid dye) for determination of waxes, pectin and proteins, respectively (Table 2). The highest degree of cellulose purity and the lowest value of waxes were obtained on cotton yarns after alkaline scouring; higher quantity of wax and pectin residues were found on alkaline pectinase scoured and the highest quantity of wax and pectin residues on acid pectinase scoured yarns (Table 2). In traditional alkaline scouring proteins are hydrolyzed to lower molecular weight components while waxes are saponified and emulsified. This process is followed with the lowest quantity of aldehyde and carboxyl groups, obtained by all used methods providing that the impurities are completely removed (Table 3). During enzymatic scouring, pectinases break down the pectin from the cuticle and thereby assist in removing of waxes, protein and other non-cellulosic components. As a result of mild working conditions and selective action of enzymes, part of the non-cellulosic residues, such as waxes, pectin and proteins remained on the cotton surface decreasing $\mathrm{L}_{\mathrm{OR}} *, \mathrm{~L}_{\mathrm{MB}} *$ and $\mathrm{L}_{\mathrm{BB}} *$ values (Table 2). Polygalacturonic acid is a main component of pectin. It contains carboxyl groups responsible for increased values of carboxyl groups on enzymatic scoured yarns (Table 3). The same examination was confirmed by Canal M. J at al. [16]. Acid pectinase scoured yarns has a higher quantity of carboxyl groups than alkaline pectinase scoured (Table 3). Acid pectinase acts in acid media promoting $\mathrm{Ca}^{2+}$ ions removal and producing higher quantity of carboxyl groups compared to scouring in alkaline media with alkaline pectinase [17].

Mercerized cotton yarns, independent of course of pretreatment, have the same trend for aldehyde and carboxyl groups as scoured. SA has the lowest quantity of aldehyde and carboxylic groups followed by SB and SN (Table 3). The results from main effects ANOVA analysis confirmed that type of scouring has a significant influence on quantity of aldehyde and carboxyl groups to all courses of pretreatment, while course of pre-treatment does no (Table 4).
The exception is only aldehyde groups determined by iodine method where course of pre-treatment has a significant influence.

Table 2. $L^{*}$ values of differently pre-treated cotton yarns dyed with Siriuslichtblau FGG $200 \%$ (Direct), Bezactiv blau HE-RM (Reactive) Oil red O (Dye for waxes), Methylene blue (Cationic dye for pectin) and Bemacid blau GLF $200 \%$ (Acid dye for protein) [12, 13]

\begin{tabular}{|l|c|c|c|c|c|}
\hline $\begin{array}{c}\text { Differently } \\
\text { pre-treated } \\
\text { cotton } \\
\text { yarns }\end{array}$ & Ldir* & Lreac* & LoR* & LMB $^{*}$ & LBB $^{*}$ \\
\hline SA & 52.945 & 48.397 & 56.47 & 66.51 & 77.22 \\
\hline SB & 52.537 & 48.287 & 52.24 & 60.58 & 74.40 \\
\hline SN & 52.405 & 48.504 & 51.83 & 58.19 & 74.41 \\
\hline MSA & 46.424 & 37.560 & 62.81 & 68.37 & 77.76 \\
\hline MSB & 44.999 & 35.573 & 57.14 & 63.94 & 73.12 \\
\hline MSN & 45.178 & 37.165 & 50.73 & 59.55 & 72.98 \\
\hline SAM & 46.461 & 34.784 & 64.99 & 68.55 & 77.62 \\
\hline SBM & 44.921 & 34.810 & 60.27 & 66.12 & 75.73 \\
\hline SNM & 43.710 & 35.123 & 56.53 & 62.62 & 75.69 \\
\hline
\end{tabular}

Table 3. Carboxyl and aldehyde groups quantity of differently pre-treated cotton yarns determined with MB, EDTA and $\mathrm{NaOH}$, I and TTC methods

\begin{tabular}{|l|c|c|c|c|c|}
\hline \multirow{2}{*}{$\begin{array}{l}\text { Differently } \\
\text { pre-treated } \\
\text { cotton yarns }\end{array}$} & \multicolumn{3}{|c|}{ COOH, mmol/kg } & \multicolumn{2}{c|}{ CHO, mmol/kg } \\
\cline { 2 - 6 } & MB & EDTA & $\mathrm{NaOH}$ & I & TTC \\
\hline SA & 12.7 & 15 & 49.6 & 18.4 & 17.2 \\
\hline SB & 19.4 & 20 & 61.6 & 23.1 & 18.2 \\
\hline SN & 21.9 & 20 & 62.4 & 50.2 & 22.4 \\
\hline MSA & 10.1 & 15 & 50 & 34.4 & 15.7 \\
\hline MSB & 24.5 & 23.5 & 57.6 & 36.2 & 18.5 \\
\hline MSN & 26.2 & 25 & 60.8 & 55.9 & 20.6 \\
\hline SAM & 12.7 & 15 & 51.2 & 55.9 & 17.5 \\
\hline SBM & 14.7 & 20 & 59.8 & 70.0 & 18.6 \\
\hline SNM & 16.9 & 25 & 62.2 & 76.6 & 20.9 \\
\hline
\end{tabular}

Iodine method is usually used for determination aldehyde groups and fine structure [18, 19]. The compositions of solutions in both cases are the same, but reaction conditions are different. In the case of aldehyde group determination, iodine acts with aldehyde groups and transform them to carboxyl [20]. In the case of fine structure (accessibility) determination, three-iodine ions form monolayer film, and therefore can be used for specific internal surface area determination [18].

Table 4. Evaluated p-values for significance of course of pretreatment and type of scouring for all investigated properties

\begin{tabular}{|l|c|c|c|c|c|}
\hline \multirow{2}{*}{ Variables } & \multicolumn{3}{|c|}{ COOH } & \multicolumn{2}{c|}{ CHO } \\
\cline { 2 - 6 } & $\mathrm{MB}$ & $\mathrm{EDTA}$ & $\mathrm{NaOH}$ & $\mathrm{I}$ & $\mathrm{TTC}$ \\
\hline $\begin{array}{l}\text { Course of pre- } \\
\text { treatment }(\mathrm{pB})\end{array}$ & 0.267 & 0.260 & 0.224 & $\mathbf{0 . 0 0 3}$ & 0.329 \\
\hline $\begin{array}{l}\text { Type of } \\
\text { scouring (pc) }\end{array}$ & 0.055 & $\mathbf{0 . 0 1 0}$ & $\mathbf{0 . 0 0 0}$ & $\mathbf{0 . 0 1 3}$ & $\mathbf{0 . 0 0 4}$ \\
\hline $\begin{array}{l}\text { Note: p-values in bold indicate significant influence on the } \\
\text { variables on investigated properties. }\end{array}$
\end{tabular}

In our case iodine reacted with aldehyde groups, but probably, also made monolayer film inside the cotton fiber surface.

In our previous investigation mercerization index by FTIR-ATR (MI), monolayer capacity (MLC) and moisture 
regain (MR) on the same yarns were determined [11]. The results showed that differently scoured-mercerized yarns have higher MI, MLC and MR than mercerized-differently scoured.

High coefficients of correlation were found between $\mathrm{L}_{\mathrm{OR}} *, \mathrm{~L}_{\mathrm{MB}} *$ and $\mathrm{L}_{\mathrm{BB}} *$ with $\mathrm{MB}, \mathrm{EDTA}, \mathrm{NaOH}$ and TTC, and also between Ldir* and Lreac* with iodine (Table 5). $\mathrm{L}_{\mathrm{OR}} *, \mathrm{~L}_{\mathrm{MB}} *$ and $\mathrm{L}_{\mathrm{BB}} *$ are methods for determination the wax, pectin and protein residues on the cotton surface, while iodine method for internal surface and accessibility determination. MB, EDTA, $\mathrm{NaOH}$ and TTC are methods that could be used mainly for surface functional groups determination (surface functionalization) while iodine method for surface as well as internal fiber functionalization.

Table 5. Coefficients of correlation between $L^{*}$ values of cotton yarns dyed with different dyes and quantity of carboxyl and aldehyde groups

\begin{tabular}{|l|c|c|c|c|c|}
\hline & $\mathrm{MB}$ & EDTA & $\mathrm{NaOH}$ & $\mathrm{I}$ & TTC \\
\hline LOR $^{*}$ & $-\mathbf{0 . 7 7 0}$ & $-\mathbf{0 . 6 0 5}$ & $-\mathbf{0 . 6 8 9}$ & -0.142 & $-\mathbf{0 . 6 7 7}$ \\
\hline LMB $^{*}$ & $\mathbf{- 0 . 8 2 2}$ & $-\mathbf{0 . 6 8 4}$ & $-\mathbf{0 . 8 3 9}$ & -0.088 & $-\mathbf{0 . 8 3 6}$ \\
\hline LBB $^{*}$ & $\mathbf{- 0 . 9 4 8}$ & $-\mathbf{0 . 8 0 9}$ & $-\mathbf{0 . 7 7 4}$ & -0.039 & $-\mathbf{0 . 6 1 8}$ \\
\hline Ldir* & -0.059 & -0.045 & -0.097 & $-\mathbf{0 . 6 8 7}$ & -0.072 \\
\hline Lreac* & 0.064 & -0.274 & 0.052 & $-\mathbf{0 . 6 4 7}$ & 0.126 \\
\hline
\end{tabular}

\subsection{Analysis of functional groups on oxidized differently pre-treated cotton yarns}

\subsubsection{Analysis of carboxyl groups}

Differently pre-treated yarns were further oxidized with perchloric acid and the results of carboxyl groups obtained with different methods are present in Table 6. Oxidized yarns keep the same behaviour of increase of MB values as un-oxidized (Table 6). Oxidized SA has the lowest value of MB, followed by oxidized SB and SN. This trend could be observed for all courses of pretreatment. Although enzymatic scoured-oxidized yrans have higher MB values than alkaline scoured-oxidized, when scoured-oxidized yarns are compared with unoxidized, alkaline scoured-oxidized (in all courses of pre-treatment) have higher percentage of increasing of MB values than enzymatic scoured-oxidized. $20 \%, 60 \%$ and $35 \%$ have increased MB values on SA-, MSA- and SAMoxidized yarns respectively, compared to unoxidized. For comparison, MB values increased $10 \%$ on enzymatic scoured and oxidized, $15 \%$ on mercerized-enzymatic scoured and oxidized and about $25 \%$ on enzymatic scoured-mercerized and oxidized yarns. Higher percentage of increased $\mathrm{MB}$ value on SA oxidized yarns (in all courses of pre-treatment) is due to completely removed cuticle and completely available cellulose surface for oxidation.

Main effects ANOVA analysis (Table 7) showed that beside oxidation and type of scouring, course of pretreatment have significant influence on MB values. While quantity of carboxyl groups of alkaline scoured yarns (oxidized and non-oxidized) are very similar in all courses of pre-treatment, quantity of carboxyl groups of enzymatic scoured yarns (oxidized and non-oxidized) differ on courses of pre-treatment. The highest values of MB have mercerized-differently scoured yarns, followed by differently scoured and differently scoured-mercerized.
Our previous results showed that significant changes occurred in cuticle structure and composition during mercerization [13]. The altered cuticle allows its different behaviour during scouring resulting in higher quantity of residual carboxyl groups and different behaviour during oxidation. That is why differently scoured-mercerized yarns have lower amount of carboxyl groups than mercerized-differently scoured $[12,13]$.

Table 6. Carboxyl groups quantity of differently pre-treated (S) and oxidized $(\mathrm{O})$ cotton yarns determined with $\mathrm{MB}$, EDTA and $\mathrm{NaOH}$ methods

\begin{tabular}{|l|c|c|c|c|c|c|}
\hline \multirow{2}{*}{$\begin{array}{l}\text { Differently } \\
\text { pre-treated } \\
\text { cotton yarns }\end{array}$} & \multicolumn{2}{|c|}{$\mathrm{MB}, \mathrm{mmol} / \mathrm{kg}$} & \multicolumn{2}{|c|}{$\mathrm{EDTA}, \mathrm{mmol} / \mathrm{kg}$} & \multicolumn{2}{|c|}{$\mathrm{NaOH}, \mathrm{mmol} / \mathrm{kg}$} \\
\cline { 2 - 7 } & $\mathrm{S}$ & $\mathrm{O}$ & $\mathrm{S}$ & $\mathrm{O}$ & $\mathrm{S}$ & $\mathrm{O}$ \\
\hline SA & 12.7 & 15.2 & 15 & 35 & 49.6 & 52.6 \\
\hline SB & 19.4 & 20.6 & 20 & 40 & 61.6 & 63.8 \\
\hline SN & 21.9 & 24.6 & 20 & 40 & 62.4 & 72.1 \\
\hline MSA & 10.1 & 16.1 & 15 & 35 & 50 & 54.6 \\
\hline MSB & 24.5 & 28.5 & 23.5 & 45 & 57.6 & 62.9 \\
\hline MSN & 26.2 & 30.8 & 25 & 45 & 60.8 & 72.4 \\
\hline SAM & 12.7 & 17.1 & 15 & 35 & 51.2 & 53.7 \\
\hline SBM & 14.7 & 18.8 & 20 & 37.5 & 59.8 & 61.7 \\
\hline SNM & 16.9 & 21.0 & 25 & 37.5 & 62.2 & 68.6 \\
\hline
\end{tabular}

Table 7. Evaluated p-values for significance of oxidation, course of pre-treatment and type of scouring for all investigated properties

\begin{tabular}{|l|c|c|c|c|c|}
\hline \multirow{2}{*}{\multicolumn{1}{|c|}{ Variables }} & \multicolumn{3}{|c|}{ COOH } & \multicolumn{2}{c|}{ CHO } \\
\cline { 2 - 6 } & MB & EDTA & NaOH & I & TTC \\
\hline Oxidation $\left(p_{A}\right)$ & $\mathbf{0 . 0 1 5 9}$ & $\mathbf{0 . 0 0 0 0}$ & $\mathbf{0 . 0 0 0 2}$ & $\mathbf{0 . 0 2 0 8}$ & $\mathbf{0 . 0 0 0 2}$ \\
\hline $\begin{array}{l}\text { Course of pre- } \\
\text { treatment }\left(\mathrm{p}_{\mathrm{B}}\right)\end{array}$ & $\mathbf{0 . 0 1 1 9}$ & $\mathbf{0 . 0 3 4 7}$ & 0.8151 & $\mathbf{0 . 0 0 0 2}$ & $\mathbf{0 . 0 3 0 9}$ \\
\hline Type of scouring $\left(\mathrm{p}_{\mathrm{C}}\right)$ & $\mathbf{0 . 0 0 0 2}$ & $\mathbf{0 . 0 0 0 1}$ & $\mathbf{0 . 0 0 0 0 0}$ & $\mathbf{0 . 0 0 0 6}$ & $\mathbf{0 . 0 0 5 2}$ \\
\hline $\begin{array}{l}\text { Note: } \text { p-values in bold indicate significant influence on the } \\
\text { variables on investigated properties. }\end{array}$ \\
\hline
\end{tabular}

Carboxyl groups obtained by complexometric titration (EDTA) are increased in all cases after oxidation. Enzymatic scoured yarns (independent of courses of pretreatment) have higher quantity of carboxyl groups than alkaline (Table 6). After oxidation the highest increase of carboxyl groups was registered on mercerized-differently scoured, followed by differently scoured and differently scoured-mercerized yarns. Main effects ANOVA analysis showed that oxidation, course of pre-treatment and type of scouring have significant influence on carboxyl groups determined by EDTA (Table 7).

Quantity of carboxyl groups of differently pre-treated yarns before and after oxidation obtained by calcium-acetate method using neutralization titration $(\mathrm{NaOH})$ is shown in Table 6. The results of carboxyl groups determined by this method are similar with the results determined by MB and EDTA methods.

\subsubsection{Analysis of aldehyde groups}

Quantity of aldehyde groups of differently pre-treated yarns after oxidation obtained by iodine and TTC methods are present in Table 8 . In all courses of pre-treatments the lowest quantity of aldehyde groups determined by iodine method was found on SA, followed by SB and the highest on SN. This trend has the same behavior as the carboxyl 
groups after oxidation. Unlike carboxyl groups, the quantity of aldehyde groups determined by iodine method decreased after oxidation with $\mathrm{HClO}_{4}$. The main reason is probably conversion of aldehyde to carboxylic groups in presence of $\mathrm{HClO}_{4}$.

Tetrazolium method showed that oxidized yarns possessed increased quantity of aldehyde groups.

Table 8. Aldehyde groups quantity of differently pre-treated (S) and oxidized (O) cotton yarns determined with (I) and (TTC) methods

\begin{tabular}{|l|c|c|c|c|}
\hline \multirow{2}{*}{$\begin{array}{c}\text { Differently } \\
\text { pre-treated } \\
\text { cotton } \\
\text { yarns }\end{array}$} & \multicolumn{2}{|c|}{$\mathrm{I}, \mathrm{mmol} / \mathrm{kg}$} & \multicolumn{2}{c|}{ TTC, $\mathrm{mmol} / \mathrm{kg}$} \\
\cline { 2 - 5 } & $\mathrm{S}$ & $\mathrm{O}$ & $\mathrm{S}$ & $\mathrm{O}$ \\
\hline SA & 18.4 & 19.7 & 17.2 & 22.8 \\
\hline SB & 23.1 & 25.4 & 18.2 & 29.2 \\
\hline SN & 50.2 & 47.8 & 22.4 & 29.1 \\
\hline MSA & 34.4 & 29.1 & 15.7 & 18.6 \\
\hline MSB & 36.2 & 30.0 & 18.5 & 24.4 \\
\hline MSN & 55.9 & 48.8 & 20.6 & 23.2 \\
\hline SAM & 55.9 & 42.2 & 17.5 & 19.7 \\
\hline SBM & 70.0 & 43.3 & 18.6 & 22.9 \\
\hline SNM & 76.6 & 51.6 & 20.9 & 21.4 \\
\hline
\end{tabular}

The highest value of TTC has SB, followed by SN and SA. The trend is the same in all courses of pre-treatment. Although aldehyde groups of oxidized yarns determined by iodine methods decreased, the increase of aldehyde groups determined by TTC is a result of high sensitivity of the TTC method. Our previous results of TTC, on the same yarns oxidized with $\mathrm{KIO}_{4}$, are $9-12$ time higher than un-oxidized (in the process of publishing). On the other hand, aldehyde groups of $\mathrm{KIO}_{4}$ oxidized yarns, measured with iodine method, increased to $\max 2.7$ times. It confirms the sensitivity of TTC.

Main effects ANOVA analysis also confirm that oxidation, course of pre-treatment and type of scouring have significant influence on aldehyde groups obtained by iodine and TTC methods (Table 7).

\subsection{Mechanical properties and degree of polymerization}

The results from the effect of oxidation on the mechanical properties are given in Table 8. Increased tensile strength of alkaline scoured yarns, in all courses of pre-treatment, was a result of increased inter fiber friction. Remained non-cellulosic components on the enzymatic scoured cotton decreased inter fiber friction and therefore they have lower tensile strength than alkaline scoured cotton [21].

Oxidation of differently pre-treated yarn decrease tensile strength. Alkaline scoured yarns have higher degree of degradation (higher decrease of tensile strength) than enzymatic scoured. The completely removed cuticle on alkaline scoured yarns did not protect cellulose from perchloric acid attack. Perchloric acid destroyed cellulose chain, and therefore decreased the tensile strength.

The works of rupture of alkaline scoured yarns are, again, higher than on enzymatic scoured. Although the work of rupture decreased after oxidation, the changes are mainly lower than on tensile strength. Maximum $15 \%$ lower tensile strength and $13 \%$ lower work of rupture after oxidation confirmed negligible degradation of oxidized cotton yarns.

The degree of oxidative degradation of cellulose was followed by the degree of polymerization before and after oxidation. DP was measured on scoured yarns (Table 10). The higher DP on enzymatic scoured yarns than alkaline is due to the mild scouring conditions. Oxidized yarns have the same trend of DP as un-oxidized. Although the oxidation with perchloric acid decreases DP, the decreasing is around $8 \%$. These results are consistent to the results of Fras L. et al. [6].

It confirmed previously discussion of mechanical properties, that oxidation of cellulose with perchloric acid is non-aggressive, and is very good method for improving functionality of cotton.

Table 9. Tensile strength, elongation and work of rupture of differently pre-treated cotton yarns before (S) and after (O) oxidation

\begin{tabular}{|c|c|c|c|c|c|c|c|c|c|c|}
\hline \multicolumn{2}{|c|}{$\begin{array}{c}\text { Differently pre-treated } \\
\text { cotton yarns }\end{array}$} & Fs, N & Fo, $\mathrm{N}$ & $\Delta \mathrm{F}, \%$ & es, $\%$ & eo, $\%$ & $\Delta \varepsilon, \%$ & As, $\mathrm{mJ}$ & Ao, $\mathrm{mJ}$ & $\Delta \mathrm{A}, \%$ \\
\hline $\mathrm{R}$ & $\begin{array}{l}\mathrm{M} \pm \mathrm{ME} \\
\mathrm{Cv}(\%)\end{array}$ & $\begin{array}{c}7.8 \pm 0.18 \\
4.96\end{array}$ & & & $\begin{array}{c}6.6 \pm 0.18 \\
6.81 \\
\end{array}$ & & & $\begin{array}{c}66.5 \pm 2.69 \\
8.65 \\
\end{array}$ & & \\
\hline SA & $\begin{array}{l}\mathrm{M} \pm \mathrm{ME} \\
\mathrm{Cv}(\%)\end{array}$ & $\begin{array}{c}9.3 \pm 0.30 \\
6.86 \\
\end{array}$ & $\begin{array}{c}8.3 \pm 0.31 \\
7.89 \\
\end{array}$ & -10.7 & $\begin{array}{c}10.1 \pm 0.31 \\
6.52\end{array}$ & $\begin{array}{c}9.3 \pm 0.39 \\
9.06\end{array}$ & -7.9 & $\begin{array}{c}90.2 \pm 4.16 \\
9.87\end{array}$ & $\begin{array}{c}78.5 \pm 3.54 \\
9.65 \\
\end{array}$ & -12.9 \\
\hline SB & $\begin{array}{l}\mathrm{M} \pm \mathrm{ME} \\
\mathrm{Cv}(\%)\end{array}$ & $\begin{array}{c}7.9 \pm 0.15 \\
4.62\end{array}$ & $\begin{array}{c}7.2 \pm 0.18 \\
5.38\end{array}$ & -8.9 & $\begin{array}{c}9.4 \pm 0.32 \\
7.31\end{array}$ & $\begin{array}{c}9.8 \pm 0.25 \\
5.50\end{array}$ & 4.2 & $\begin{array}{l}73.7 \pm 2.85 \\
9.55\end{array}$ & $\begin{array}{c}68.4 \pm 2.90 \\
9.04\end{array}$ & -7.2 \\
\hline SN & $\begin{array}{l}\mathrm{M} \pm \mathrm{ME} \\
\mathrm{Cv}(\%)\end{array}$ & $\begin{array}{c}7.7 \pm 0.24 \\
6.68\end{array}$ & $\begin{array}{c}7.1 \pm 0.25 \\
7.55\end{array}$ & -7.8 & $\begin{array}{l}9.6 \pm 0.25 \\
5.58\end{array}$ & $\begin{array}{c}9.3 \pm 0.35 \\
7.98\end{array}$ & -3.1 & $\begin{array}{c}70.4 \pm 3.25 \\
9.86\end{array}$ & $\begin{array}{c}66.0 \pm 2.50 \\
8.08\end{array}$ & -6.2 \\
\hline MSA & $\begin{array}{l}\mathrm{M} \pm \mathrm{ME} \\
\mathrm{Cv}(\%)\end{array}$ & $\begin{array}{c}16.0 \pm 0.41 \\
5.92\end{array}$ & $\begin{array}{c}14.3 \pm 0.42 \\
6.19\end{array}$ & -10.6 & $\begin{array}{c}7.7 \pm 0.23 \\
6.30 \\
\end{array}$ & $\begin{array}{c}8.0 \pm 0.29 \\
7.87\end{array}$ & 3.9 & $\begin{array}{c}120.7 \pm 5.49 \\
9.73 \\
\end{array}$ & $\begin{array}{c}114.4 \pm 4.50 \\
9.26\end{array}$ & -5.2 \\
\hline MSB & $\begin{array}{l}\mathrm{M} \pm \mathrm{ME} \\
\mathrm{Cv}(\%)\end{array}$ & $\begin{array}{c}14.9 \pm 0.55 \\
7.98 \\
\end{array}$ & $\begin{array}{c}12.6 \pm 0.40 \\
6.74\end{array}$ & -15.4 & $\begin{array}{c}6.8 \pm 0.25 \\
9.08 \\
\end{array}$ & $\begin{array}{c}7.8 \pm 0.21 \\
5.74 \\
\end{array}$ & 14.7 & $\begin{array}{c}102.1 \pm 4.05 \\
9.20 \\
\end{array}$ & $\begin{array}{c}101.1 \pm 4.36 \\
9.23 \\
\end{array}$ & -1.0 \\
\hline MSN & $\begin{array}{l}\mathrm{M} \pm \mathrm{ME} \\
\mathrm{Cv}(\%)\end{array}$ & $\begin{array}{c}12.7 \pm 0.46 \\
7.65\end{array}$ & $\begin{array}{c}11.2 \pm 0.33 \\
6.23\end{array}$ & -11.8 & $\begin{array}{c}7.5 \pm 0.24 \\
6.91\end{array}$ & $\begin{array}{c}7.0 \pm 0.22 \\
6.81\end{array}$ & -6.7 & $\begin{array}{c}97.1 \pm 4.70 \\
10.35\end{array}$ & $\begin{array}{c}92.4 \pm 4.19 \\
9.68\end{array}$ & -4.8 \\
\hline SAM & $\begin{array}{l}\mathrm{M} \pm \mathrm{ME} \\
\mathrm{Cv}(\%)\end{array}$ & $\begin{array}{c}16.1 \pm 0.49 \\
6.52\end{array}$ & $\begin{array}{l}15.2 \pm 0.55 \\
7.66\end{array}$ & -5.6 & $\begin{array}{c}5.3 \pm 0.24 \\
9.68\end{array}$ & $\begin{array}{c}6.4 \pm 0.22 \\
7.49\end{array}$ & 20.7 & $\begin{array}{l}99.0 \pm 4.42 \\
9.54\end{array}$ & $\begin{array}{c}87.3 \pm 2.41 \\
9.00\end{array}$ & -11.8 \\
\hline SBM & $\begin{array}{l}\mathrm{M} \pm \mathrm{ME} \\
\mathrm{Cv}(\%)\end{array}$ & $\begin{array}{c}13.9 \pm 0.40 \\
6.71 \\
\end{array}$ & $\begin{array}{c}13.7 \pm 0.24 \\
3.79 \\
\end{array}$ & -1.4 & $\begin{array}{c}6.6 \pm 0.24 \\
6.64 \\
\end{array}$ & $\begin{array}{c}7.0 \pm 0.20 \\
7.15 \\
\end{array}$ & 6.1 & $\begin{array}{c}92.6 \pm 3.90 \\
8.36 \\
\end{array}$ & $\begin{array}{c}82.0 \pm 3.38 \\
8.79 \\
\end{array}$ & -11.4 \\
\hline SNM & $\begin{array}{l}\mathrm{M} \pm \mathrm{ME} \\
\mathrm{Cv}(\%)\end{array}$ & $\begin{array}{c}14.8 \pm 0.42 \\
6.09\end{array}$ & $\begin{array}{c}14.4 \pm 0.45 \\
6.68\end{array}$ & -2.7 & $\begin{array}{c}5.5 \pm 0.21 \\
8.13\end{array}$ & $\begin{array}{c}6.4 \pm 0.26 \\
8.72\end{array}$ & 16.4 & $\begin{array}{c}94.0 \pm 3.95 \\
8.99\end{array}$ & $\begin{array}{c}92.2 \pm 4.50 \\
9.89\end{array}$ & -1.9 \\
\hline
\end{tabular}


Table 10. Degree of polymerization of differently pre-treated (S) and oxidized $(\mathrm{O})$ cotton yarns

\begin{tabular}{|c|c|c|}
\hline \multirow{2}{*}{ Type of pre-treatment } & \multicolumn{2}{|c|}{ DP } \\
\cline { 2 - 3 } & $\mathrm{S}$ & $\mathrm{O}$ \\
\hline SA & 1222.5 & 1121.4 \\
\hline SB & 1647.4 & 1529.9 \\
\hline SN & 1346.3 & 1259.9 \\
\hline
\end{tabular}

\section{CONCLUSION}

As a result of measured properties and as a result of discussions, following conclusions can be made:

Type of scouring processes of cotton yarns have significant influence on the quantity of carboxyl and aldehyde groups before non-selective oxidation with perchloric acid, while course of pre-treatment does no. Alkaline scoured cotton yarns (in all courses of pretreatment) have the lowest quantity of carboxyl and aldehyde groups followed by alkaline pectinse and acid pectinase scoured.

Quantity of carboxyl and aldehyde groups on differently pre-treated and oxidized cotton yarns significantly depends of oxidation, course of pretreatments and type of scouring. In terms of course of pretreatment, the highest quantity of carboxyl groups has mercerized-differently scoured, followed by differently scoured and differently scoured-mercerized oxidized cotton.

$15 \%$ lower tensile strength, $13 \%$ lower work of rupture as well as $8 \%$ lower DP after oxidation confirms that oxidation with perchloric acid is good method for improving functionality on cotton fibers without its significant degradation.

\section{REFERENCES}

1. Knittel, D., Schollmeyer, E. Technologies for a New Century. Surface Modification of Fibres The Journal of the Textile Institute 91 (3) 2000: pp. 151-163.

2. Strand, S., Šauper, O., Jazbec, A., Kleinschek, S.K. Influence of Chemical Modification on Sorption and Mechanical Properties of Cotton Fibers Treated with Chitosan Textile Research Journal 78 (5) 2008: pp. 390-398.

3. Biliuta, G., Fras, L., Drobota, M., Persin, Z., Kreze, T., Kleinschek, S.K., Ribitsch, V., Harabagiu, V., Coseri, S. Comparison Study of TEMPO and Phthalimide-N-Oxyl (PINO) Radicals on Oxidation Efficiency Toward Cellulose Carbohydrate Polymers 91 (2) 2013: pp. 502-507.

4. Kim, J.U., Kuga, S. Reactive Interaction of Aromatic Amines with Dialdehyde Cellulose Gel Cellulose 7 (3) 2000: pp. $287-297$.

5. Diankova, M. Sv., Doneva, D.M. Analysis of Oxycellulose Obtained by Partial Oxidation with Different Reagents Bulgarian Chemical Communications 41 (4) 2009: pp. $391-396$.

6. Fras, L., Kleinschek, S.K., Ribitsch, V., Smole, S.M., Kreze, T. Quantitative Determination of Carboxyl Groups in Cellulose by Complexometric Titration Materials Research Innovations 8 (3) 2004: pp. $145-146$.
7. Milanović, J., Kosić, M., Škundrić, P. Structure and Properties of TEMPO-Oxidized Cotton Fibers Chemical Industry and Chemical Engineering Quarterly (CI\&CEQ) 18 (3) 2012: pp. 473-481.

8. Saito, T., Isogai, A. TEMPO-Mediated Oxidation of Native Cellulose. The Effect of Oxidation Conditions on Chemical and Crystal Structures of the Water-Insoluble Fractions Biomacromolecules 5 (5) 2004: pp. 1983-1989.

9. Coseri, S., Biliuta, G., Simionescu, C.B., Kleinschek, S.K., Ribitsch, V., Harabagiu, V. Oxidized Cellulose-Survey of the Most Recent Achievements Carbohydrate Polymers 93 (1) 2013: pp. 207-215.

10. Hon, D.N.S. Cellulose and Its Derivatives: Structure, Reactions, ad Mediacl Uses. In Dumitriu (Ed.) Polysaccharides in Medical Application 1996: pp. 87-105.

11. Jordanov, I., Mangovska, B. Accessibility of Mercerized, Bioscoured and Dried Cotton Yarns Indian Journal of Fiber \& Textile Research 36 (3) 2011: pp. 259-265.

12. Jordanov, I., Mangovska, B. Characterization on Surface of Mercerized and Enzymatic Scoured Cotton after Different Temperature of Drying The Open Textile Journal 2 2009: pp. 39-47.

13. Jordanov, I., Mangovska, B., Simonic, B., TavcerForte, P. Changes in the Non-cellulosic Components of Cotton Surface after Mercerization and Scouring AATCC Review 10 (6) 2010: pp. 65-72.

14. Kumar, V., Yang, T. $\mathrm{HNO}_{3}-\mathrm{H}_{3} \mathrm{PO}_{4}$ Mediated Oxidation of Cellulose-Preparation and Characterization of Bioabsorbable Oxidized Celluloses in High Yields and with Different Levels of Oxidation Carbohydrate Polymers 48 (4) 2002: pp. $403-412$.

15. Strlić, M., Pihlar, B. Determination of Reducing Carbonyl Groups in Cellulose in the Solvent System LiCl/N,Ndimethylethylacetamide Fresenium' Journal Analytical Chemistry 357 (6) 1997: pp. 670-675. http://dx.doi.org/10.1007/s002160050232

16. Canal, M.J., Navarro, A., Calafell, M., Rodriguez, C., Caballero, G., Vega, B., Canal, C., Paul, R. Effect of Various Bioscouring Systems on the Accessibility of Dyes into Cotton Coloration Technology $120(6)$ 2004: pp. $311-315$.

17. Jordanov, I., Mangovska, B. Enzymatic Scouring of Cotton Knitted Fabrics with Acid Pectinase, Cellulase and Lacase Vlakna a Textile 14 (3-4) 2007: pp. 28 -40.

18. Nikolić, T., Kostić, M., Praskalo, J., Petronijević, Ž., Škundrić, P. Sorption Properties of Periodate Oxidized Cotton Chemical Industry and Chemical Engineering Quarterly (CI\&CEQ) 17 (3) 2011: pp. 367-374.

19. Fras, L., Šauperl, O. Chitosan and Its Derivatives as an Adsorbate for Cellulose Anti-microbial Functionalizations Industria Textilă 63 (6) 2012: pp. 296-301.

20. Arthur, I. Vogel, Elementary Practical Organic Chemistry Part III. Longman Group Limited, London, 1958: pp. $741-742$.

21. Buschle-Diller, G.M.K., Inglesby, K.M., El-Moghazy, Y., Zeronian, H.S. The Effect of Scouring Using Enzymes, Organic Solvents and Caustic Soda on the Properties of Hydrogen Peroxide Bleached Cotton Yarn Textile Research Journal 68 (12) 1998: pp. 920-929. 